\title{
A New Assistant Method for Characterizing Ablation Resistance of ZrC-SiC Dispersive Biphasic Coating on C/C Composites
}

\author{
Tao Feng ${ }^{1, *}$, Mingde Tong ${ }^{2}$, Shuotian Yao ${ }^{1}$ and Shifeng Wen ${ }^{1}$ \\ 1 School of Mechanics, Civil Engineering \& Architecture, Northwestern Polytechnical University, Xi'an 710072, \\ Shaanxi, China; yaoshuotian@mail.nwpu.edu.cn (S.Y.); wenshifeng@nwpu.edu.cn (S.W.) \\ 2 State Key Laboratory of Solidification Processing, Shaanxi Key Laboratory of Fiber Reinforced Light \\ Composite Materials, Northwestern Polytechnical University, Xi'an 710072, Shaanxi, China; \\ marktong@mail.nwpu.edu.cn \\ * Correspondence: fengtao@nwpu.edu.cn; Tel./Fax: +86-29-88431002
}

Received: 19 August 2019; Accepted: 16 October 2019; Published: 6 November 2019

\begin{abstract}
To optimize the ablation resistance of $\mathrm{ZrC}$ coating, $\mathrm{ZrC}-\mathrm{SiC}$ dispersive biphasic coating was prepared by chemical vapor co-deposition. The ablation resistances of the coatings were carried out by oxyacetylene flame tests. Compared with double-layered $\mathrm{ZrC} / \mathrm{SiC}$ coating, the ablation resistance of $\mathrm{ZrC}-\mathrm{SiC}$ coating was evaluated. On the basis of similar mass ablation rates of the two coatings, a new assistant method for characterizing the thermal protecting effect of coatings on carbon-carbon composites $(\mathrm{C} / \mathrm{C})$ composites was proposed. The thermal protecting ability of the coating was accurately reflected by the changes of hardness and elastic modulus of $\mathrm{C} / \mathrm{C}$ substrate below the central region of ablated coatings before and after ablation. The ablation processes of two kinds of coatings were also discussed. The results showed that the hardness and elastic modulus of the $\mathrm{C} / \mathrm{C}$ substrate protected by $\mathrm{ZrC}-\mathrm{SiC}$ coating were higher than that of $\mathrm{C} / \mathrm{C}$ coated with $\mathrm{ZrC} / \mathrm{SiC}$ coating. The result convincingly illustrated the thermal protecting ability of $\mathrm{ZrC}-\mathrm{SiC}$ coating was much better than that of $\mathrm{ZrC} / \mathrm{SiC}$ coating, which attributed to the formation of $\mathrm{Zr}$-Si-O glass.
\end{abstract}

Keywords: ZrC-SiC coating; chemical vapor deposition; ablation resistance; ultrahigh temperature ceramic

\section{Introduction}

Carbon-carbon composites $(\mathrm{C} / \mathrm{C})$ have been widely applied in the aerospace industry, especially in ultrahigh-temperature thermal structural materials because of their excellent high-temperature mechanical properties [1-5]. However, in an ablation environment, rapid oxidation will occur, which reduces the mechanical property rapidly $[5,6]$. To guarantee the mechanical properties of $\mathrm{C} / \mathrm{C}$ composites at high temperature, thermal protecting coatings are necessary. As a kind of ultrahigh- temperature ceramics (UHTC), zirconium carbide $(\mathrm{ZrC})$ is regarded as a potential material for thermal protecting coating material to prevent $\mathrm{C} / \mathrm{C}$ composites from ablation owing to its high melting point, good tribological behavior, thermal stability, high hardness, and low vapor pressure [7-11]. Besides, $\mathrm{ZrO}_{2}$ (the oxidation product of $\mathrm{ZrC}$ ) possesses a high melting point and low vapor pressure [12,13]. Up to now, in some reports, $\mathrm{ZrC}$ coating has been fabricated by chemical vapor deposition (CVD) [14,15], which is suitable for preparing UHTC coatings on thin-wall products with relatively low deposition temperature. Wang S. et al. [16] successfully prepared CVD-ZrC coating and studied its ablation resistance under different heat fluxes.

Although $\mathrm{ZrC}$ is a promising candidate for thermal protecting coating, the combination of single $\operatorname{ZrC}\left(\alpha_{\mathrm{ZrC}} \approx 7.6 \times 10^{-6}{ }^{\circ} \mathrm{C}\right)$ layer and $\mathrm{C} / \mathrm{C}$ substrate $\left(\alpha_{\mathrm{C} / \mathrm{C}} \approx 1.1 \times 10^{-6}{ }^{\circ} \mathrm{C}\right)$ is disadvantageous because of the vast difference between the thermal expansion coefficients (CTE) of the two materials. To resolve 
the problem, different efforts have been devoted to relieving the thermal stress between $\mathrm{ZrC}$ coating and $\mathrm{C} / \mathrm{C}$ substrate [17-23]. After many attempts, it has been found that $\mathrm{SiC}\left(\alpha_{\mathrm{SiC}} \approx 4.4 \times 10^{-6}{ }^{\circ} \mathrm{C}\right)$ is suitable as a transition layer and can relatively relieve the mismatch of CTE between the outer $\mathrm{ZrC}$ coating and inner $\mathrm{C} / \mathrm{C}$ substrate. In addition, the oxide of $\mathrm{SiC}\left(\mathrm{SiO}_{2}\right)$ has a self-healing capacity and good oxygen diffusion blocking effect below $1700^{\circ} \mathrm{C}$ [20,24-26]. However, $\mathrm{ZrC} / \mathrm{SiC}$ double-layered coating also has some problems, such as higher expense, the difficulty of fabrication, and the stress concentration at interfaces. Moreover, it has been reported that $\mathrm{ZrC}$ coating will be powdered and oxidized to produce $\mathrm{ZrO}_{2}$ during the ablation process [14], which will reduce the cohesion of the coating. Therefore, serious mechanical denudation will take place under high speed oxyacetylene flame and particles, leading to high depletion of the coating. In view of the above problem, some researchers proposed using a thermal evaporation method and in situ reaction to prepare $\mathrm{ZrC}-\mathrm{SiC}$ biphasic coating [27], inhibiting the mechanical denudation efficaciously. Nevertheless, this method has high cost, higher preparation temperature, and complex steps. Especially, the biphasic ceramic particles ( $\mathrm{SiC}$ and $\mathrm{ZrC}$ ) present mosaic distribution leading to large reaction-diffusion free path. To reduce the preparation temperature and make the biphasic ceramic particles $(\mathrm{ZrC}$ and $\mathrm{SiC}$ ) disperse uniform distribution, one-step chemical vapor deposition is a good choice.

Up to now, many works about ablation behavior of single coating ( $\mathrm{ZrC}$ coating, SiC coating) or multilayers coating ( $\mathrm{ZrC} / \mathrm{SiC}$ coating) has been reported [28,29]. Little work is reported about the ablation behavior of $\mathrm{ZrC}-\mathrm{SiC}$ double-phase coating fabricated by a one-step CVD method [30]. Linear and mass ablation rates are common methods for characterizing ablation resistance of thermal protective coatings. Nevertheless, the ablation process is often accompanied with the generating of oxidation products [24] resulting in mass increase of the coating materials. Thus, the oxidation of coating materials leads to mass gain; but the mechanical erosion of the coating and oxidation of $\mathrm{C} / \mathrm{C}$ substrate results in mass loss. Therefore, it is difficult to analyze the reasons for mass changes of specimens after ablation. It is also confused to judge the ablation resistances of protective coatings for $\mathrm{C} / \mathrm{C}$ composites just from mass ablation rates. In addition, the coating will become thicker due to the phase transition of $\mathrm{ZrO}_{2}$. The volume and weight changes of coatings may influence the linear and mass ablation rates of the coatings. So, the ablation rates could not present the thermal protecting effect accurately. Based on this problem, a new method characterizing thermal protective effect for $\mathrm{C} / \mathrm{C}$ composites has been proposed in this paper.

In the present study, $\mathrm{ZrC}-\mathrm{SiC}$ double-phase coating was fabricated by one-step chemical vapor deposition at a relatively low temperature. The phase composition and microstructure were characterized. The ablation test was carried out on oxyacetylene ablator. The thermal protective ability of the coating was accurately reflected by the change of hardness and elastic modulus of $C / C$ substrate before and after ablation.

\section{Material and Methods}

\subsection{Materials and Preparation}

$\mathrm{C} / \mathrm{C}$ composite $\left(1.7 \mathrm{~g} \cdot \mathrm{cm}^{-3}\right)$, which would be used as substrate of coatings, prepared by chemical vapor infiltration (CVI) were machined into a dimension of $\Phi 30 \times 6 \mathrm{~mm}^{3}$. After 340 and 500 mesh sandpaper grinding, all specimens were cleaned with ethanol. Then, the specimens were dried for $8 \mathrm{~h}$ to stand by.

The ZrC-SiC biphasic coating was deposited by one-step chemical vapor deposition on the surface of $\mathrm{C} / \mathrm{C}$ substrates with $\mathrm{ZrCl}_{4}-\mathrm{CH}_{4}-\mathrm{Si}_{-} \mathrm{H}_{2}-\mathrm{Ar}$ system. Among them, $\mathrm{ZrCl}_{4}$ (purity: $98.7 \%$ ) acts as $\mathrm{Zr}$ source precursor of $\mathrm{ZrC}$; $\mathrm{Si}$ powder acts as $\mathrm{Si}$ source of $\mathrm{SiC} ; \mathrm{CH}_{4}$ gas provides $\mathrm{C}$ source of the two ceramics; $\mathrm{H}_{2}$ and Ar are reductive and protective gases, respectively. The schematic diagram of the deposition equipment is shown in Figure 1a. The powder feeder can precisely control the feeding rate of $\mathrm{ZrCl}_{4}$ precursor. 
(a)

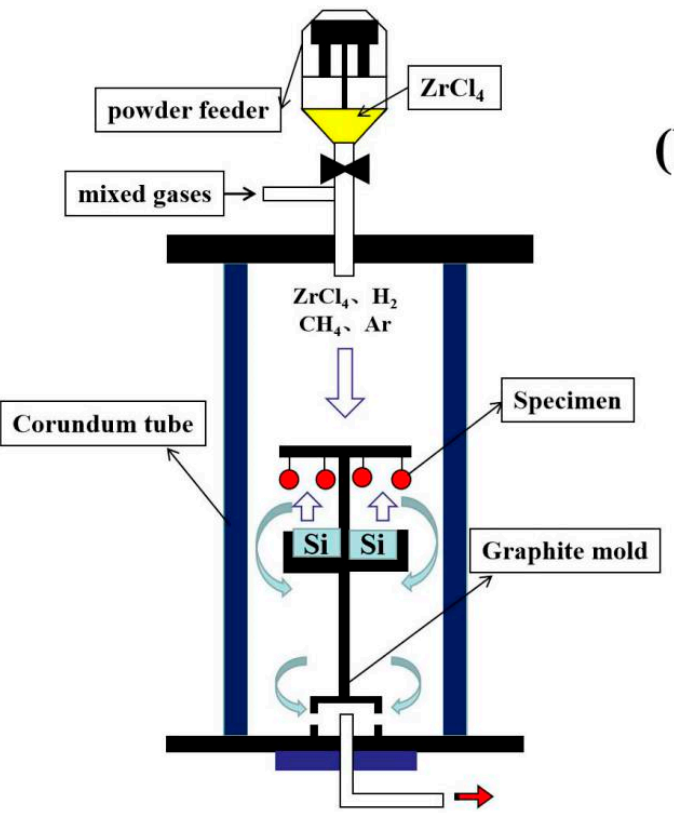

(b)

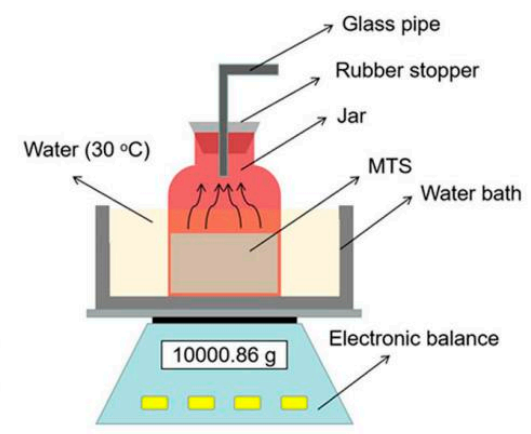

Figure 1. The schematic sketches of $\mathrm{ZrC}-\mathrm{SiC}$ biphasic coating deposition equipment (a) and introducing method of methyltrichlorosilane (MTS) (b).

The specimens prepared above were positioned in the constant temperature area of the furnace. The deposition temperature was $1350 \sim 1550{ }^{\circ} \mathrm{C}$; and the pressure inside the furnace cavity ranged from 10 40 kPa. The feeding rate of $\mathrm{ZrCl}_{4}$ was $0.7 \pm 0.1 \mathrm{~g} / \mathrm{min}$. The flow speeds of $\mathrm{CH}_{4}, \mathrm{H}_{2}$, and $\mathrm{Ar}$ were $100 \pm 50 \mathrm{~mL} / \mathrm{min}, 1500 \pm 400 \mathrm{~mL} / \mathrm{min}$, and $200 \pm 50 \mathrm{~mL} / \mathrm{min}$, respectively. The deposition process lasted for $8 \mathrm{~h}$; the heating and cooling rates were both $7.0^{\circ} \mathrm{C} / \mathrm{min}$.

For comparison, the double-layered $\mathrm{ZrC} / \mathrm{SiC}$ coating was also deposited by two-step CVD. Firstly, the specimens were positioned in the constant temperature region to prepare $\mathrm{SiC}$ coating with methyltrichlorosilane (MTS)- $\mathrm{H}_{2}-\mathrm{Ar}$ deposition system. The methyltrichlorosilane (MTS) was introduced by volatilization at low pressure and constant temperature $\left(30^{\circ} \mathrm{C}\right)$ shown in Figure $1 \mathrm{~b}$. The deposition temperature was $1250^{\circ} \mathrm{C}$; the feeding rate of MTS was $0.3 \pm 0.05 \mathrm{~g} / \mathrm{min}$; the flowing rates of $\mathrm{H}_{2}$ and Ar were $1000 \pm 300 \mathrm{~mL} / \mathrm{min}$ and $200 \pm 40 \mathrm{~mL} / \mathrm{min}$, respectively; the deposition process lasted for $8 \mathrm{~h}$. After that, the specimens coated with $\mathrm{SiC}$ coating were put into the furnace again for $\mathrm{ZrC}$ layer deposition. During the deposition process, the temperature was $1350 \sim 1550{ }^{\circ} \mathrm{C}$; the flow rates of gases including $\mathrm{CH}_{4}, \mathrm{H}_{2}$, and Ar were $80 \pm 20 \mathrm{~mL} / \mathrm{min}, 800 \pm 200 \mathrm{~mL} / \mathrm{min}$ and $100 \pm 20 \mathrm{~mL} / \mathrm{min}$, respectively. The heating and cooling rates of two deposition processes were all $7.0^{\circ} \mathrm{C} / \mathrm{min}$.

\subsection{Performance Tests}

The ablation resistances of $\mathrm{ZrC} / \mathrm{SiC}$ coating and $\mathrm{ZrC}-\mathrm{SiC}$ coating were characterized through oxyacetylene flame test according to the GJB323A-96 ablation standard of China [20]. The standard mainly unified and testified the ablation properties of high-temperature composites and coatings to obtain linear ablation rate and mass ablation rate. The specific test parameters were as follows: The oxyacetylene flame was perpendicular to the center of specimens coated with coatings. The distance between the gun tip and the surface of the specimen was $10 \mathrm{~mm}$. The diameter of oxyacetylene flame core was $2 \mathrm{~mm}$. The pressures of $\mathrm{O}_{2}$ and $\mathrm{C}_{2} \mathrm{H}_{2}$ were $0.4 \mathrm{MPa}$ and $0.095 \mathrm{MPa}$, respectively. The flow rates of $\mathrm{O}_{2}$ and $\mathrm{C}_{2} \mathrm{H}_{2}$ were $0.244 \mathrm{~L} / \mathrm{s}$ and $0.167 \mathrm{~L} / \mathrm{s}$, respectively.

The ablation resistances of the coatings were reflected by linear and mass ablation rates. And the equations were displayed as the following:

$$
R_{l}=\frac{\Delta d}{t}
$$




$$
R_{m}=\frac{\Delta m}{t}
$$

where $R_{l}$ means linear ablation rate, $R_{m}$ means mass ablation rate, $\Delta d$ and $\Delta m$ are the changes of thickness and mass, respectively, and $t$ is the ablation time.

Because the volume change and warping of the coatings may influence the linear and mass ablation rates of the coatings, the ablation rates could not present the thermal protecting effect accurately. To confirm the protective effect of the two coatings, the hardness and elastic modulus of the $\mathrm{C} / \mathrm{C}$ substrates coated by two ablated coatings were measured and compared. Micro indentation tests were carried out with MHT-M system produced by NANOVEA. The maximum load was $4 \mathrm{~N}$, and the loading increasing rate was set as $8 \mathrm{~N} / \mathrm{min}$.

\subsection{Morphology and Phase Characterization Method}

The phase composition and microstructure were investigated by X-ray diffraction (XRD, X'Pert Pro MPD), scan electron microscope (SEM, Tescan Vega 3) with energy dispersive spectroscopy (EDS, INCA).

\section{Results and Discussion}

\section{Composition and Microstructure of the Coatings}

After deposition processes, the phase compositions of the coatings were characterized. The results are shown in Figure 2. From the XRD pattern of $\mathrm{ZrC} / \mathrm{SiC}$ coating (curve a), it is revealed that there are only several $\mathrm{ZrC}$ characteristic peaks, indicating that there is no other phase on the surface of the specimens coated with the double-layered coating. Judging from the narrow peaks of $\mathrm{ZrC}$ (pdf: 65-4932) peaks of two patterns in Figure 2, the ZrC phases in two coatings presented high crystalline. Meanwhile, it can be observed that curve $\mathrm{b}$ contains both $\mathrm{SiC}$ and $\mathrm{ZrC}$ peaks implying $\mathrm{ZrC}-\mathrm{SiC}$ coating is a dispersive double-phase coating consisting of $\mathrm{ZrC}$ and $\mathrm{SiC}$ phases.

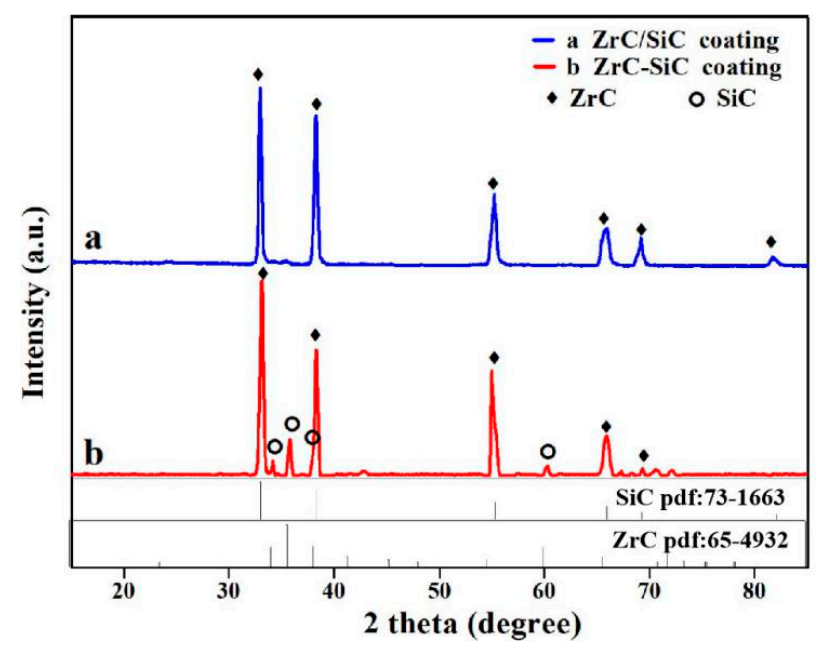

Figure 2. The $\mathrm{XRD}$ results of $\mathrm{ZrC} / \mathrm{SiC}$ and $\mathrm{ZrC}-\mathrm{SiC}$ coatings.

The SEM pictures of double-layered $\mathrm{ZrC} / \mathrm{SiC}$ coating and $\mathrm{ZrC}-\mathrm{SiC}$ coating are exhibited in Figure 3. From Figure $3 \mathrm{a}$, the surface of $\mathrm{ZrC} / \mathrm{SiC}$ coating is relatively smooth; no hole can be found on the surface of the coating. It can be seen that the cracking of the double-layered $\mathrm{ZrC} / \mathrm{SiC}$ coating is obvious. The surface morphology of $\mathrm{ZrC}-\mathrm{SiC}$ coating is rougher than that of double-layered $\mathrm{ZrC} / \mathrm{SiC}$ coating; but the cracks cannot be found on the coating surface. The thickness of $\mathrm{ZrC} / \mathrm{SiC}$ coating is about $50 \sim 70 \mu \mathrm{m}$. Combining with Figure $3 \mathrm{~b}, \mathrm{e}, \mathrm{f}$, there is an obvious gap in the double-layered $\mathrm{ZrC} / \mathrm{SiC}$ coating implying the poor bonding strength between different layers, which may be caused by the thermal stress concentration at interface generated during deposition process. That of $\mathrm{ZrC}-\mathrm{SiC}$ coating 
(about 40 60 $\mu \mathrm{m}$ ) is much different: Two ceramic phases ( $\mathrm{SiC}$ and $\mathrm{ZrC}$ ) disperse uniformly with each other from Figure 3d. Comparing with the cross-section of the two coatings mentioned above, it can be deduced that stress concentration could be relieved in $\mathrm{ZrC}-\mathrm{SiC}$ coating significantly. Because the CTE of $\operatorname{SiC}$ phase $\left(\alpha_{\mathrm{SiC}} \approx 4.4 \times 10^{-6}{ }^{\circ} \mathrm{C}^{-1}\right)$ is much lower than that of $\operatorname{ZrC}\left(\alpha_{\mathrm{ZrC}} \approx 7.6 \times 10^{-6}{ }^{\circ} \mathrm{C}^{-1}\right)$, the CTE of diphasic $\mathrm{ZrC}-\mathrm{SiC}$ can be calculated by Equation (3).

$$
\alpha_{Z S}=\alpha_{S} \cdot v_{S}+\alpha_{Z} \cdot v_{z}
$$

where $\alpha_{Z S}, \alpha_{S}$, and $\alpha_{Z}$ are the CTE of diphasic ZrC-SiC, SiC and ZrC phases, respectively; $v_{S}$ and $v_{Z}$ are the volume ratios of $\mathrm{SiC}$ and $\mathrm{ZrC}$ phases.

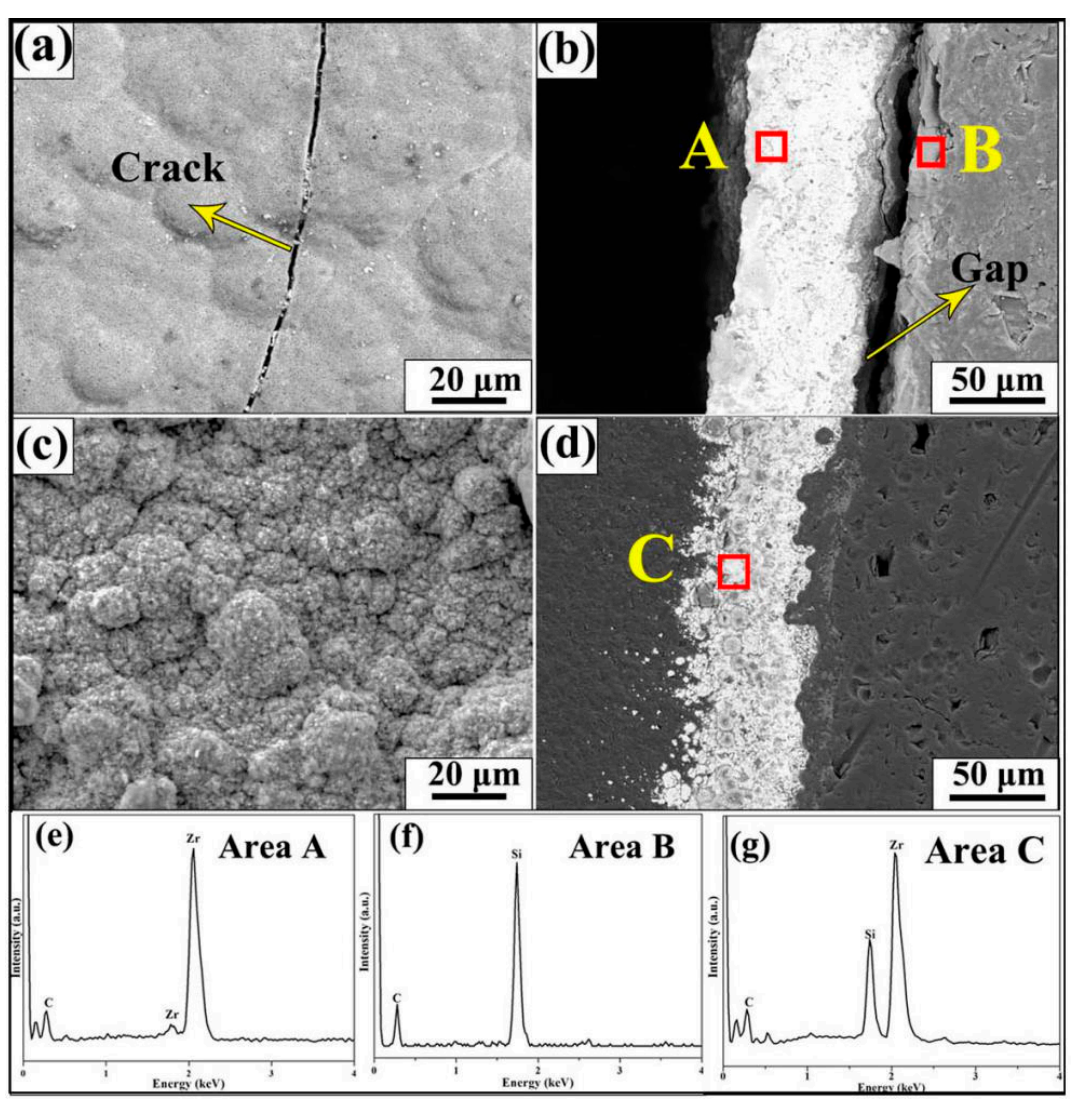

Figure 3. The surface morphology of $\mathrm{ZrC} / \mathrm{SiC}$ coating (a) and $\mathrm{ZrC}-\mathrm{SiC}$ coating (c); the cross-section of $\mathrm{ZrC} / \mathrm{SiC}$ coating $(\mathbf{b})$ and $\mathrm{ZrC}-\mathrm{SiC}$ coating $(\mathbf{d})$; the electron spectroscopy (EDS) results of Area A (e), Area B (f) and Area C (g).

Therefore, the mismatch between the $\mathrm{ZrC}-\mathrm{SiC}$ double-phase coating and $\mathrm{C} / \mathrm{C}$ substrate is lower than that of $\mathrm{C} / \mathrm{C}$ coated with $\mathrm{ZrC}$ coating. Besides, there is no phase interface of different layers where stress concentration always occurs.

After ablation tests for $60 \mathrm{~s}$, the linear and mass ablation rates of two prepared coatings were obtained as displayed in Figure 4. The linear and mass ablation rates of $\mathrm{ZrC} / \mathrm{SiC}$ coating were $0.402 \pm 0.03 \mu \mathrm{m} / \mathrm{s}$ and $0.18 \pm 0.03 \mathrm{mg} / \mathrm{s}$; and those of $\mathrm{ZrC}$-SiC coating were $0.153 \pm 0.02 \mu \mathrm{m} / \mathrm{s}$ and $0.19 \pm 0.05 \mathrm{mg} / \mathrm{s}$. Compared with $\mathrm{ZrC} / \mathrm{SiC}$ coating, the linear ablation rate of $\mathrm{ZrC}-\mathrm{SiC}$ coating decreased by $75 \%$; the mass ablation rate of $\mathrm{ZrC} / \mathrm{SiC}$ and $\mathrm{ZrC}-\mathrm{SiC}$ coating were nearly similar. 


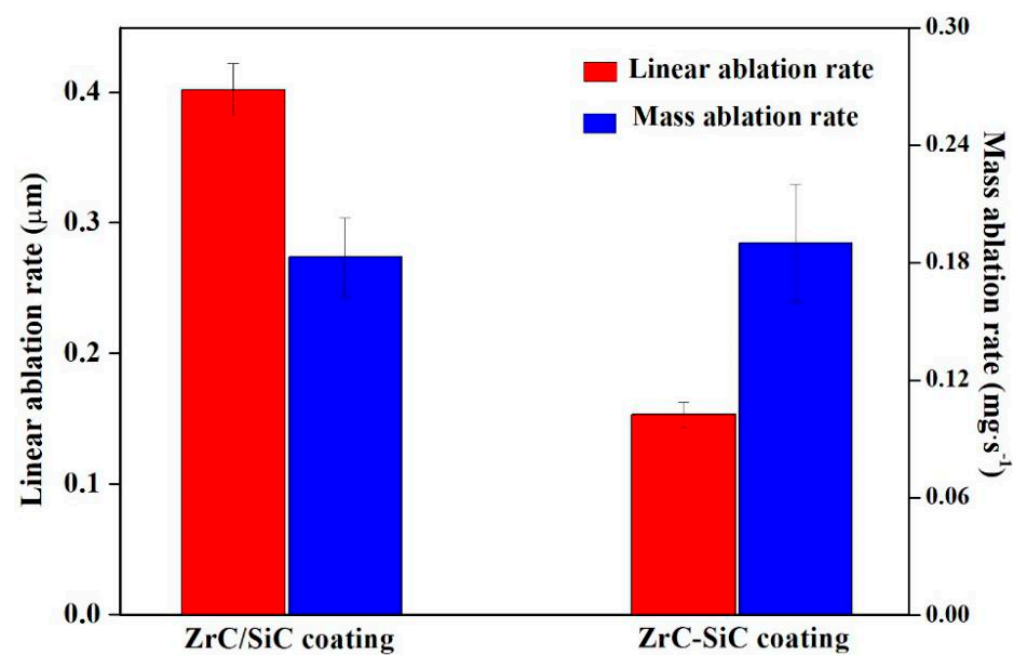

Figure 4. The results of ablation tests.

To analyze the reason for lower linear ablation rate of $\mathrm{ZrC}-\mathrm{SiC}$ coating, the phase compositions of two ablated coatings were characterized by XRD. Figure 5 exhibits the XRD patterns of ablated $\mathrm{ZrC} / \mathrm{SiC}$ and $\mathrm{ZrC}-\mathrm{SiC}$ coatings. It can be observed that the ablated double-layered $\mathrm{ZrC} / \mathrm{SiC}$ coating consists of $\mathrm{ZrO}_{2}$ and $\mathrm{SiC}$ phases. Obviously, the phases in ablated $\mathrm{ZrC}-\mathrm{SiC}$ are different than those of $\mathrm{ZrC} / \mathrm{SiC}$ coating including not only $\mathrm{ZrO}_{2}$ and $\mathrm{SiO}_{2}$, but also $\mathrm{ZrSiO}_{4}$, which may attribute to the dispersion distribution of $\mathrm{ZrC}$ and $\mathrm{SiC}$ phases. Based on the above results, it could be inferred that peeling and denudation of the double-layered $\mathrm{ZrC} / \mathrm{SiC}$ coating occurred during the ablation process.

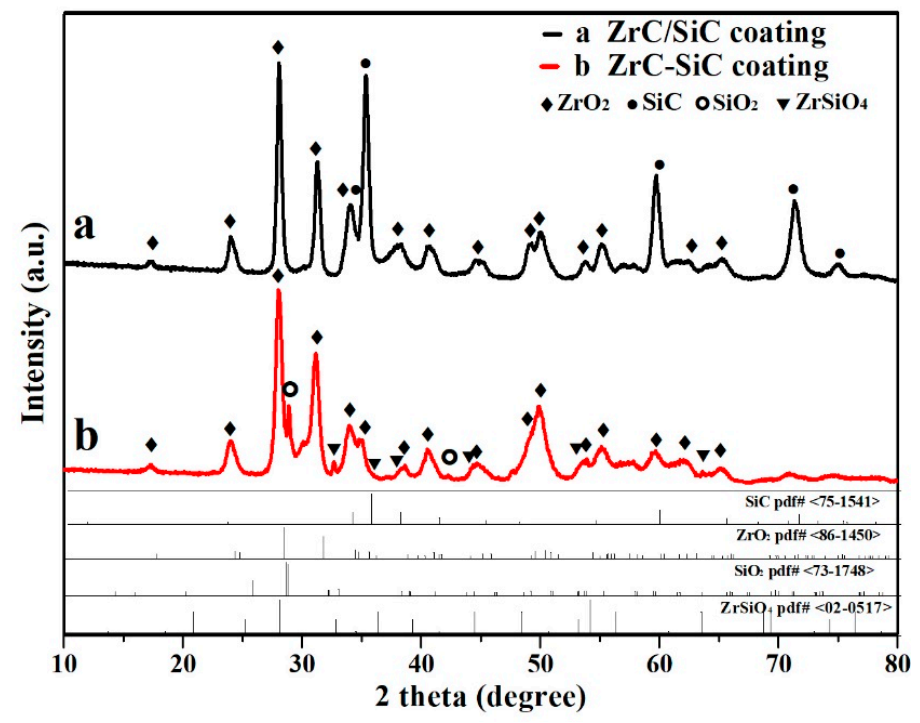

Figure 5. The $\mathrm{XRD}$ patterns of $\mathrm{ZrC} / \mathrm{SiC}$ and $\mathrm{ZrC}-\mathrm{SiC}$ coatings after ablation.

Figure 6 shows the macroscopic pictures of two ablated specimens. From the macroscopic morphology of $\mathrm{ZrC} / \mathrm{SiC}$ coating (Figure $6 \mathrm{a}, \mathrm{c}$ ), there are plenty of cracks on its surface. Meanwhile, the damage traces at the central ablation area is obvious, resulting in the serious mechanical denudation. On the contrary, the surface of ablated $\mathrm{ZrC}-\mathrm{SiC}$ coating was intact with no obvious cracks, indicating that the mechanical denudation was inhibited effectively. Meanwhile, no damage trace can be seen from Figure $6 \mathrm{~b}, \mathrm{~d}$. Comparing the macroscopic morphologies, it can be concluded that the mechanical denudation resistance of $\mathrm{ZrC}-\mathrm{SiC}$ coating is higher than that of double-layered $\mathrm{ZrC} / \mathrm{SiC}$ coating. 


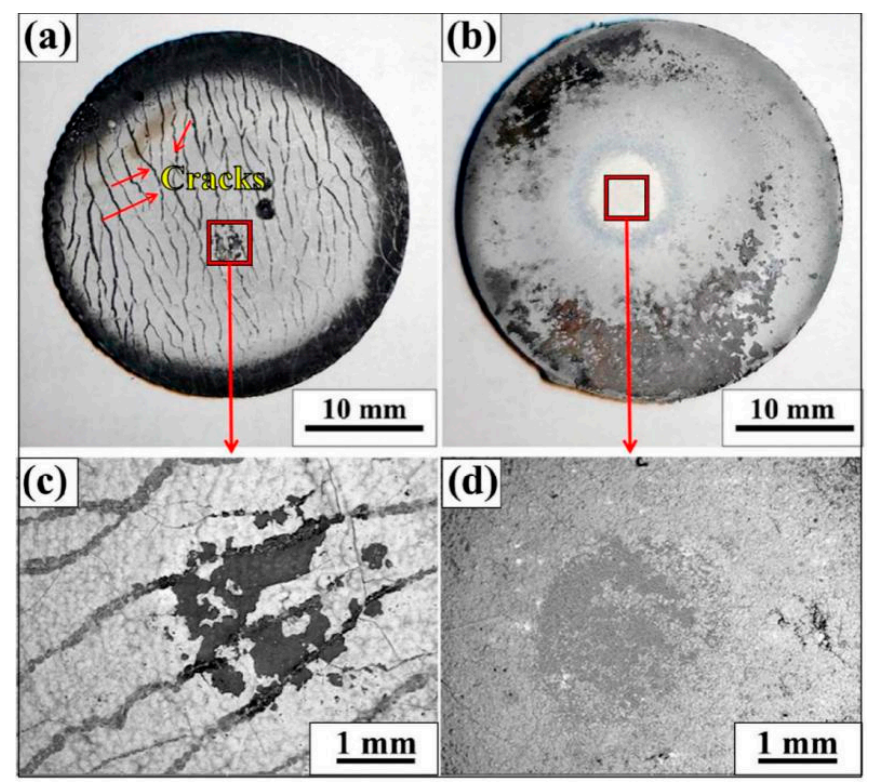

Figure 6. The macroscopic and SEM pictures of ablated $\mathrm{ZrC} / \mathrm{SiC}$ coating $(\mathbf{a}, \mathbf{c})$ and $\mathrm{ZrC}-\mathrm{SiC}$ coating $(\mathbf{b}, \mathbf{d})$.

Figure 7 reflects the morphology of $\mathrm{ZrC} / \mathrm{SiC}$ and $\mathrm{ZrC}-\mathrm{SiC}$ coatings at the central ablation region. Figure $7 \mathrm{a}, \mathrm{c}$ corresponds to the central ablation region of $\mathrm{ZrC} / \mathrm{SiC}$ coating. Serious warpage and mechanical denudation occurred in the central ablation zone, so that the outer $\mathrm{ZrO}_{2}$ layer was exfoliated and inner SiC layer was exposed and oxidized, which is consistent with the XRD result of ablated $\mathrm{ZrC} / \mathrm{SiC}$ coating. Observed from Figure $7 \mathrm{c}$, grain boundary and crack are obvious among $\mathrm{ZrO}_{2}$ grains. Besides, the sizes of $\mathrm{ZrO}_{2}$ grains are about $2 \sim 4 \mu \mathrm{m}$. From Figure $7 \mathrm{~b}$, it is exciting that the surface of the ablated $\mathrm{ZrC}-\mathrm{SiC}$ coating kept intact with no exfoliation. The surface is similar to a bubbly-like structure. From Figure 7d, no obvious grain boundary and crack could be seen. The $\mathrm{ZrO}_{2}$ grain sizes of ablated $\mathrm{ZrC}-\mathrm{SiC}$ coating are smaller than that of ablated $\mathrm{ZrC} / \mathrm{SiC}$ coating. The holes (shown in Figure $7 \mathrm{c}, \mathrm{d}$ ) are generated due to the oxidation of $\mathrm{ZrC}$ accompanied with $\mathrm{CO}$ gas. $\mathrm{CO}$ gas is hardly insoluble in $\mathrm{ZrO}_{2}$, resulting in the connected holes formed by the escaping of $\mathrm{CO}$.

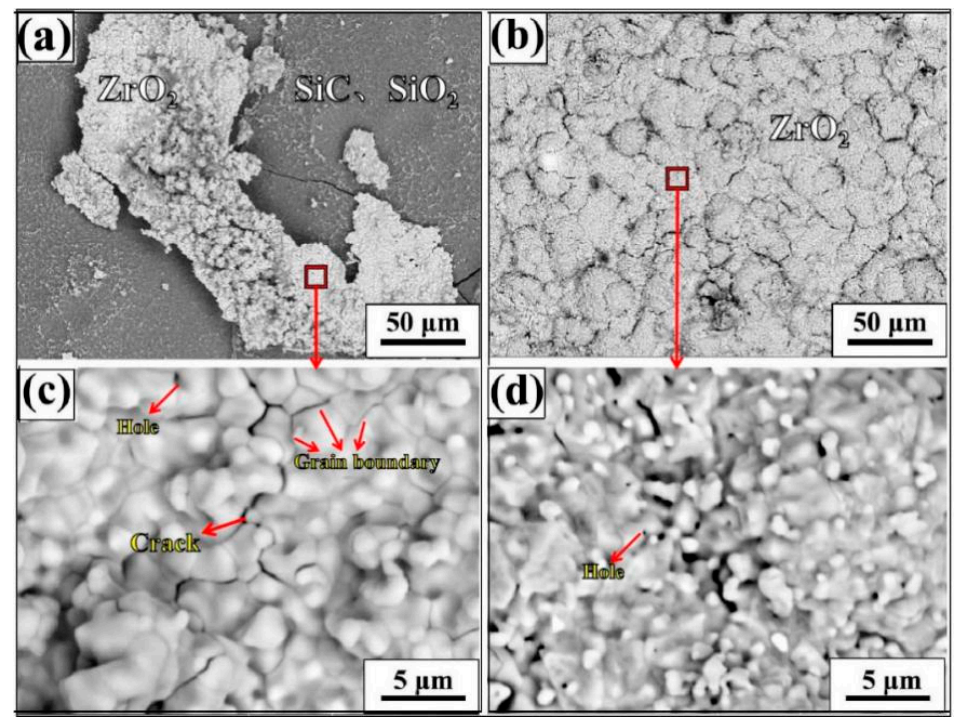

Figure 7. The surface morphology of ablated $\mathrm{ZrC} / \mathrm{SiC}$ coating $(\mathbf{a}, \mathbf{c})$ and $\mathrm{ZrC}-\mathrm{SiC}$ coating $(\mathbf{b}, \mathbf{d})$ at central ablation region. 
The morphology of ablated $\mathrm{ZrC} / \mathrm{SiC}$ and $\mathrm{ZrC}-\mathrm{SiC}$ coatings at the transition ablation region present as shown in Figure 8. On the surface of the ablated $\mathrm{ZrC} / \mathrm{SiC}$ coating, obvious cracks and exposed inner $\mathrm{SiC}$ layer can be found, implying that cracking and denudation occurred during the ablation process. Moreover, it can be clearly observed from Figure 8a that the mechanical denudation of the $\mathrm{ZrO}_{2}$ layer along the direction of the crack propagation is especially serious. The cracking phenomenon may be caused by the CTE mismatch between $\mathrm{SiC}$ and $\mathrm{ZrC}$. On the contrary, there is neither cracking nor damage at the transition region of ablated $\mathrm{ZrC}-\mathrm{SiC}$ coating. Combining the XRD (shown in Figure 5) and EDS (shown in Figure 9 Area $\mathrm{C}$ ) results, it can be implied that the gray phase is $\mathrm{Zr}$-Si-O glass phase $\left(\mathrm{ZrO}_{2}-\mathrm{ZrSiO}_{4}-\mathrm{SiO}_{2}\right)$. From Figure $8 \mathrm{~b}$, the gray glass phase and white phase present mosaic distribution indicating the adhesion effect of the glass phase. Because of the adhesion effect, $\mathrm{ZrO}_{2}$ grains were trapped by the sticky glass phase during ablation, resulting in that the mechanical denudation of $\mathrm{ZrC}-\mathrm{SiC}$ coating was inhibited.
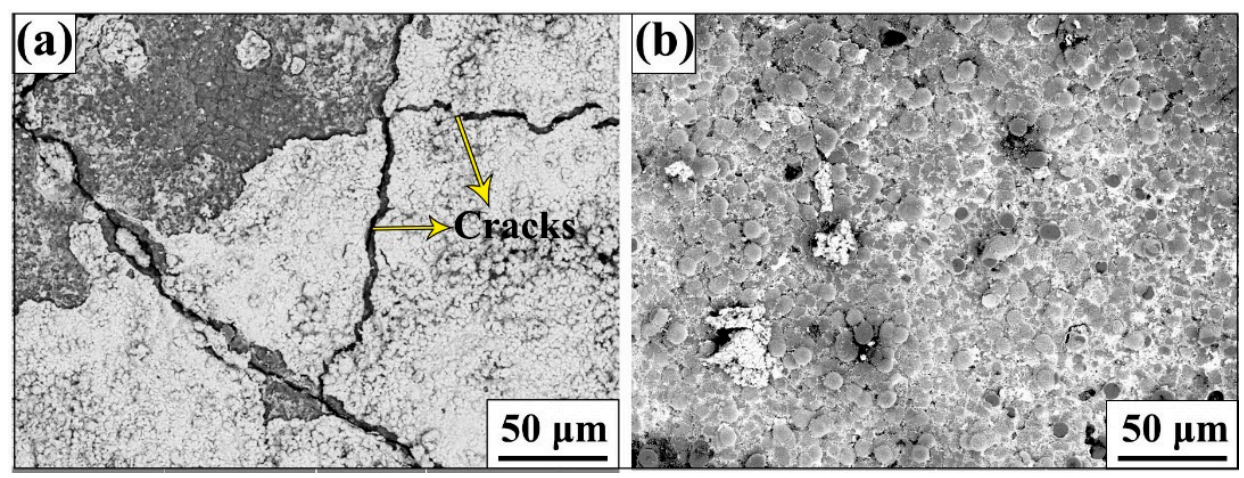

Figure 8. The SEM pictures of ablated $\mathrm{ZrC} / \mathrm{SiC}$ coating (a) and $\mathrm{ZrC}-\mathrm{SiC}$ coating (b) at transition ablation region.

The morphology of cross-section is an impactful way to confirm the consumption of the coating during the ablation process. Figure 9 displays the cross-section morphology of ablated $\mathrm{ZrC} / \mathrm{SiC}$ coating and $\mathrm{ZrC}-\mathrm{SiC}$ coating. Meanwhile, it also gives the element compositions of two ablated coatings. Observing Figure $9 \mathrm{a}$, there is an obvious gap between the outer layer and inner layer, which may influence the judgment from the ablation rates. Correspondingly, no gap can be seen from Figure 9b, illustrating that the stress concentration phenomenon did not occur in $\mathrm{ZrC}-\mathrm{SiC}$ coating during ablation. Ignoring the gap, the thickness of the ablated $\mathrm{ZrC} / \mathrm{SiC}$ double-layer coating decreased a lot compared with Figure 3b. Meanwhile, the thickness decreasing of $\mathrm{ZrC}-\mathrm{SiC}$ coating was less than that of the $\mathrm{ZrC} / \mathrm{SiC}$ double-layer coating, illustrating that the mechanical erosion of $\mathrm{ZrC}-\mathrm{SiC}$ coating was slighter than that of $\mathrm{ZrC} / \mathrm{SiC}$ coating during the ablation process. Combining the $\mathrm{XRD}$ result, it can be confirmed the phase composition of ablated $\mathrm{ZrC}-\mathrm{SiC}$ coating was $\mathrm{Zr}$-Si-O glass phase. Observed from Figure $9 \mathrm{~b}$, the gray phase can be seen in $\mathrm{C} / \mathrm{C}$ substrate. And the EDS result of the gray phase illustrated the phase is $\mathrm{SiC}$, which means $\mathrm{Si}$ element diffused into $\mathrm{C} / \mathrm{C}$ substrate during the ablation process.

From the linear ablation rate results, the ablation resistance of $\mathrm{ZrC}-\mathrm{SiC}$ coating might be better than that of double-layered $\mathrm{ZrC}-\mathrm{SiC}$ coating. But the mass ablation rates of the two coatings are similar, which is miserable to judge the ablation resistance. During the ablation test, the oxidation of coating materials is the main reason for mass gain. Meanwhile, the mechanical erosion of coating and oxidation of $\mathrm{C} / \mathrm{C}$ substrate are the reasons for mass loss. Therefore, oxidation degrees, densities, and mechanical denudation of coatings can influence the mass ablation rates. The reactions of the coated specimens are as follows:

$$
\begin{gathered}
\mathrm{ZrC}(\mathrm{s})+2 \mathrm{O}_{2}(\mathrm{~g}) \rightarrow \mathrm{ZrO}_{2}(\mathrm{~s})+\mathrm{CO}_{2}(\mathrm{~g}) \\
\mathrm{SiC}(\mathrm{s})+2 \mathrm{O}_{2}(\mathrm{~g}) \rightarrow \mathrm{SiO}_{2}(\mathrm{~s})+\mathrm{CO}_{2}(\mathrm{~g})
\end{gathered}
$$




$$
\begin{gathered}
\mathrm{SiO}_{2}(\mathrm{~s})+\mathrm{ZrO}_{2}(\mathrm{~s}) \rightarrow \mathrm{ZrSiO}_{4}(\mathrm{~s}) \\
\mathrm{C}(\mathrm{s})+\mathrm{O}_{2}(\mathrm{~g}) \rightarrow \mathrm{CO}_{2}(\mathrm{~g}) \\
2 \mathrm{C}(\mathrm{s})+\mathrm{O}_{2}(\mathrm{~g}) \rightarrow 2 \mathrm{CO}(\mathrm{g})
\end{gathered}
$$

According to the above-mentioned reactions, the reactions (Equations (4) and (5)) lead to mass gain, and the reactions (Equations (7) and (8)) lead to mass loss. Moreover, the coating materials might be consumed to result in mass loss by the mechanical denudation from airflow scouring. Therefore, mass ablation rates cannot reflect directly and accurately the ablation resistances of coatings.

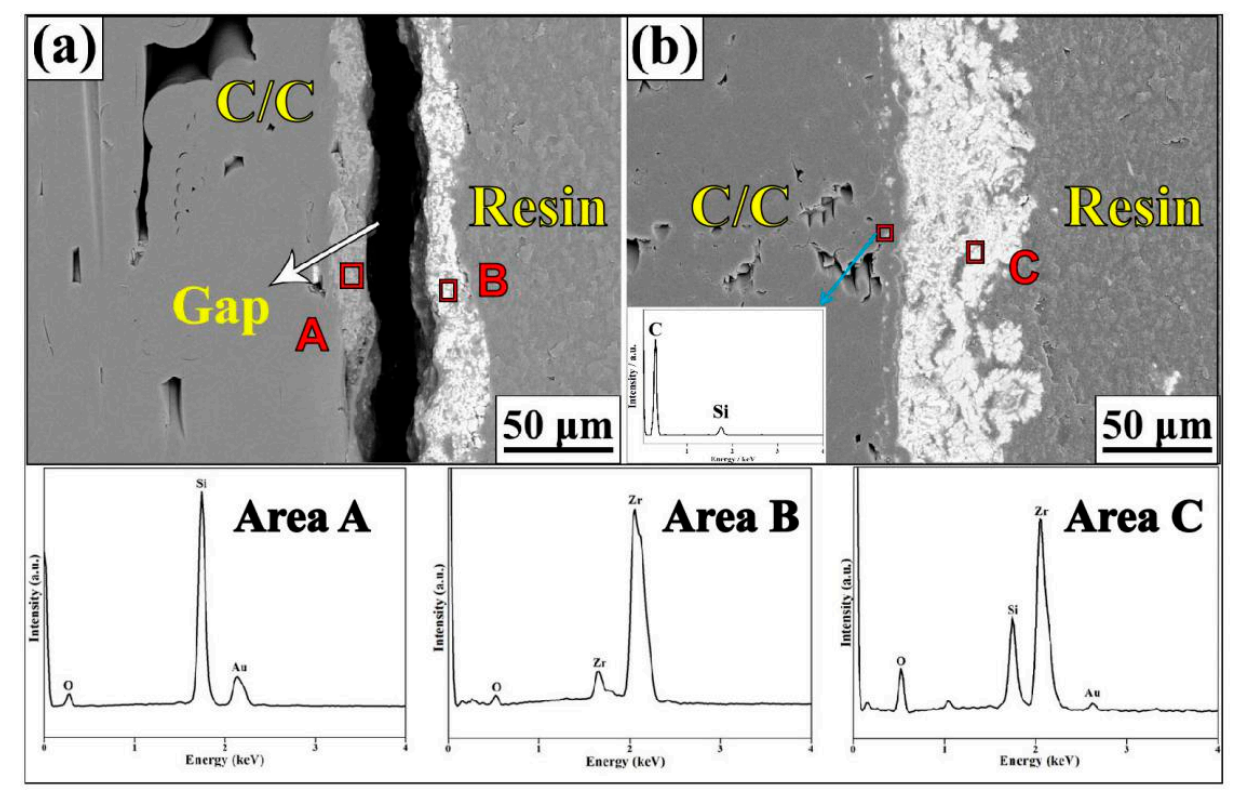

Figure 9. The cross-section morphology and corresponding EDS results of ablated $\mathrm{ZrC} / \mathrm{SiC}$ and $\mathrm{ZrC}-\mathrm{SiC}$ coatings. (a) ablated $\mathrm{ZrC} / \mathrm{SiC}$ coating; (b) ablated $\mathrm{ZrC}-\mathrm{SiC}$ coating.

As the warping and weight gain due to oxidation of the coating may affect the accuracy of the judgment from the ablation rates, the thermal protection effect of the two coatings needs to be judged by the mechanical properties of $\mathrm{C} / \mathrm{C}$ substrates below ablated coatings as assistant method. Figure 10 shows the results of micro-indentation tests to $\mathrm{C} / \mathrm{C}$ substrates covered by $\mathrm{ZrC} / \mathrm{SiC}$ and $\mathrm{ZrC}-\mathrm{SiC}$ coatings before and after ablation for $60 \mathrm{~s}$. From Figure 10a,c, the hardness and elastic modulus of C/C substrate covered by $\mathrm{ZrC} / \mathrm{SiC}$ coating decreased by $17 \%$ and $20 \%$, respectively, after ablation, which was caused by the oxidation of $\mathrm{C} / \mathrm{C}$ composite. On the contrary, it is interesting that the hardness of $\mathrm{C} / \mathrm{C}$ substrate covered by $\mathrm{ZrC}-\mathrm{SiC}$ coating increased rather than decreased after ablation for $60 \mathrm{~s}$, which was caused by diffusion of $\mathrm{Si}$ element during high-temperature $\left(>2000{ }^{\circ} \mathrm{C}\right)$ ablation. The elastic modulus of $\mathrm{C} / \mathrm{C}$ substrate below $\mathrm{ZrC}-\mathrm{SiC}$ coating increased slightly after ablation. Comparing the hardness and modulus of elasticity changes of $\mathrm{ZrC} / \mathrm{SiC}$ and $\mathrm{ZrC}-\mathrm{SiC}$ coatings before and after ablation for $60 \mathrm{~s}$, it can be inferred that the latter has better thermal protection property.

In addition, before ablation, the hardness and modulus of $\mathrm{C} / \mathrm{C}$ substrate covered by $\mathrm{ZrC}-\mathrm{SiC}$ coating were higher than that of substrate covered by $\mathrm{ZrC} / \mathrm{SiC}$ coating, which was caused by the damage from twice thermal cycle shock during the deposition process of $\mathrm{ZrC} / \mathrm{SiC}$ coating. Meanwhile, the damage on hardness and elastic modulus of the substrate below $\mathrm{ZrC}-\mathrm{SiC}$ coating prepared by one-step CVD were relatively little. 

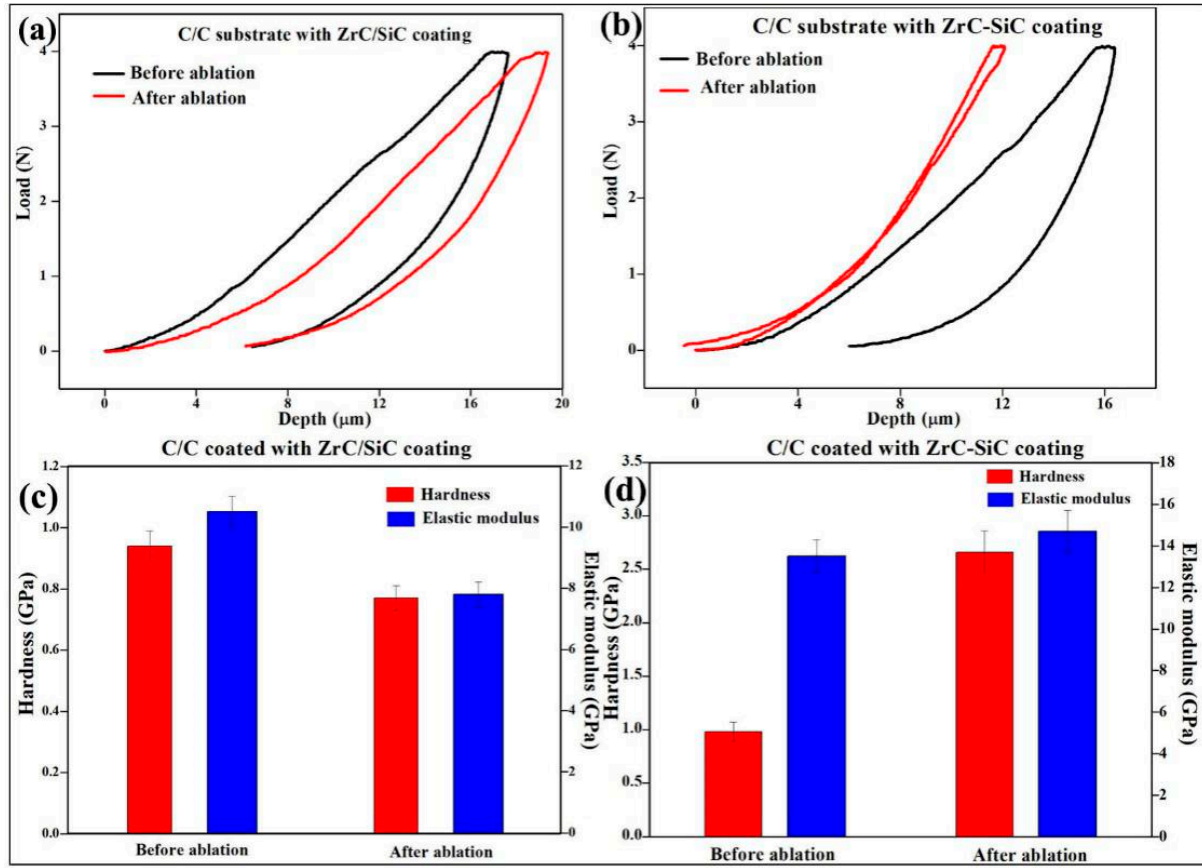

Figure 10. The micro-indentation test results of $\mathrm{C} / \mathrm{C}$ substrates covered by $\mathrm{ZrC} / \mathrm{SiC}$ and $\mathrm{ZrC}-\mathrm{SiC}$ coatings before and after ablation for $60 \mathrm{~s}$. The load-depth curves (a) and mechanical properties (c) of $\mathrm{C} / \mathrm{C}$ substrate coated with $\mathrm{ZrC} / \mathrm{SiC}$ double-layer coating before and after ablation; (b) and mechanical properties $(\mathbf{d})$ of $\mathrm{C} / \mathrm{C}$ substrate coated with $\mathrm{ZrC}-\mathrm{SiC}$ coating before and after ablation.

We studied the phase transition of $\mathrm{C} / \mathrm{C}$ substrates during high-temperature ablation. The raman spectrum results of $\mathrm{C} / \mathrm{C}$ substrates covered by $\mathrm{ZrC} / \mathrm{SiC}$ coating and $\mathrm{ZrC}-\mathrm{SiC}$ coating before and after ablation exhibited are displayed Figure 11. It can be seen that the intensity ratio of the $\mathrm{D}$ and $\mathrm{G}$ peaks decrease after ablation for $60 \mathrm{~s}$, meaning that the graphitization transition occurred during the ablation process. After a certain degree of graphitization transition, the elastic modulus increased slightly.

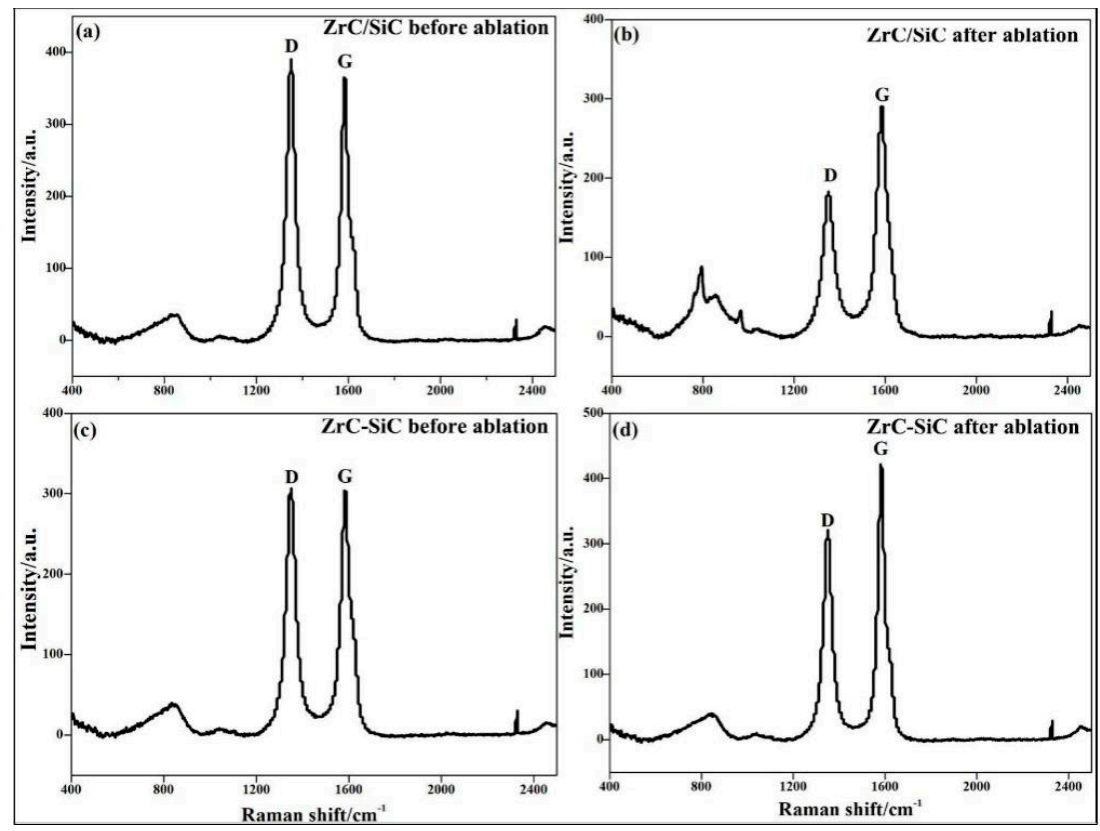

Figure 11. The raman spectrum results of $\mathrm{C} / \mathrm{C}$ substrates covered by $\mathrm{ZrC} / \mathrm{SiC}$ coating and $\mathrm{ZrC}-\mathrm{SiC}$ coating before and after ablation. (a) $\mathrm{C} / \mathrm{C}$ coated with $\mathrm{ZrC} / \mathrm{SiC}$ coating; (b) $\mathrm{C} / \mathrm{C}$ coated with ablated $\mathrm{ZrC} / \mathrm{SiC}$ coating; (c) C/C coated with ZrC-SiC coating; (d) C/C coated with ablated ZrC-SiC coating. 
Based on all the above results, the ablation mechanism of the two coatings can be concluded (shown in Figure 12). Because of the CTE mismatch between the $\mathrm{SiC}$ and $\mathrm{ZrC}$ phases, the peeling phenomenon occurred during $\mathrm{ZrC} / \mathrm{SiC}$ coating deposition process (shown in Figure $3 \mathrm{~b}$ ). Moreover, the oxidation of $\mathrm{ZrC}$ is accompanied with $\mathrm{CO}$ gas escaping and the generation of porous $\mathrm{ZrO}_{2}$ structure during the ablation process. Then the cohesion of outer $\mathrm{ZrO}_{2}$ became weak, resulting in serious mechanical denudation under high speed airflow and particles scouring. These explanations can be confirmed from Figures $6 \mathrm{c}$ and $7 \mathrm{a}$. After that, the damages were generated. The damages could be new paths for oxygenated gas diffusing into inner $\mathrm{C} / \mathrm{C}$ substrate, which led to the reduction of its hardness and elastic modulus. The $\mathrm{CO}$ and $\mathrm{CO}_{2}$ gases generated from the oxidation of $\mathrm{C} / \mathrm{C}$ substrate would accelerate the damages of ablated $\mathrm{ZrC} / \mathrm{SiC}$ coating.

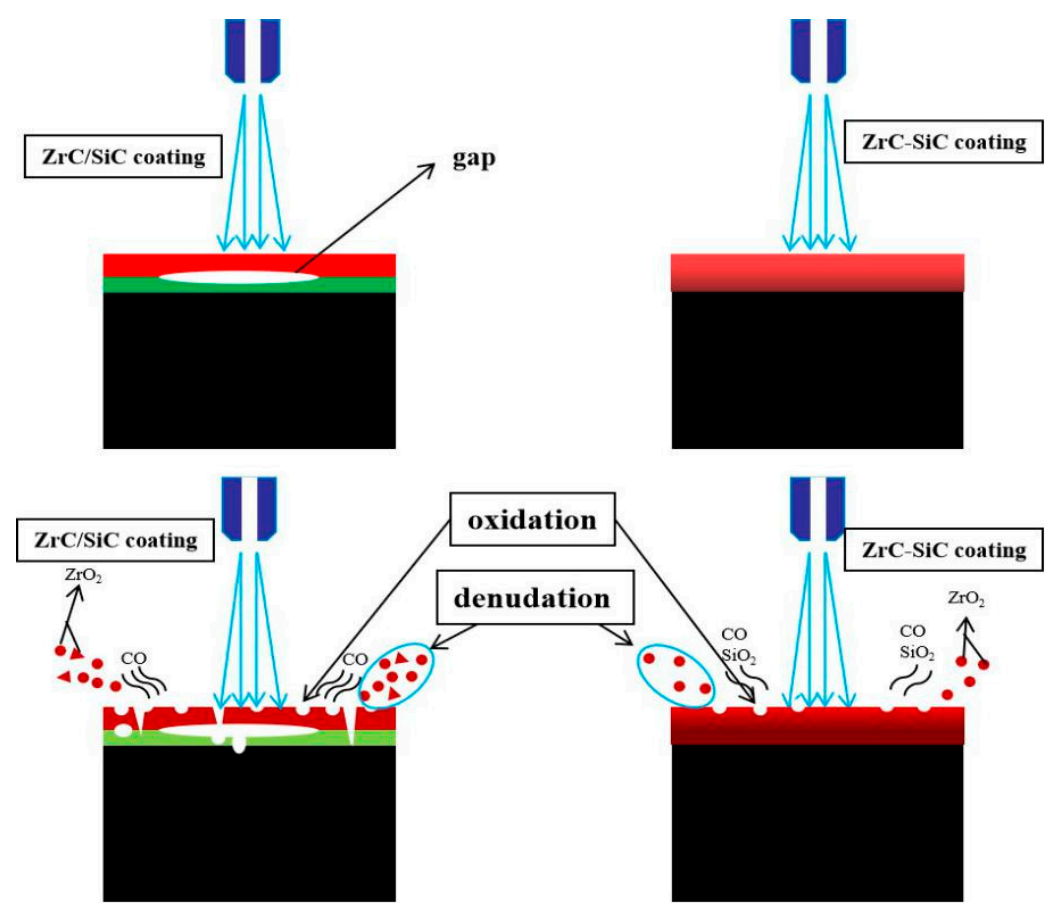

Figure 12. The diagram of $\mathrm{ZrC} / \mathrm{SiC}$ and $\mathrm{ZrC}-\mathrm{SiC}$ coatings during ablation process.

On the contrary, the $\mathrm{ZrC}-\mathrm{SiC}$ coating fabricated by one-step chemical vapor deposition is different. Firstly, ZrC-SiC coating has no interface between different ceramic layers, indicating that the stress concentration phenomenon could not occur at the interface of different layers. Secondly, the oxygen diffusion blocking effect of $\mathrm{Zr}$-Si-O glass would protect the inner coating from further oxidation; and the adhesion effects could inhibit the powdering oxidation of $\mathrm{ZrC}$, $\operatorname{trap} \mathrm{ZrO}_{2}$ grains, and reduce depletion of coating materials. So, the decrease of the cohesion of the coating would be inhibited effectively. Therefore, the surface of the coating could remain intact after ablation for $60 \mathrm{~s}$; and the inner $\mathrm{C} / \mathrm{C}$ substrate was prevented from oxidation. Without oxidation and damages, the hardness and elastic modulus of $\mathrm{C} / \mathrm{C}$ substrate would maintain well. These explanations can be supported by Figure $3 c, d$, Figures 4, 7, 9 and 10.

\section{Expectation}

$\mathrm{C} / \mathrm{C}$ composites are potential thermal structure materials in the aerospace field. Various kinds of coatings for protecting $\mathrm{C} / \mathrm{C}$ composites under oxidation and ablation environment have been reported in recent years. However, traditional judging standard (linear and mass ablation rates) could not accurately characterize the protective effects of the coatings gradually. Based on this problem, the new assistance method introduced in this paper can effectively and accurately judge the ablation resistance 
of coatings under the condition of low cost. It also might be a new standard to judge the ablation resistances of coatings for protecting $\mathrm{C} / \mathrm{C}$ composites in the future.

\section{Conclusions}

To protect $\mathrm{C} / \mathrm{C}$ composites from ablation, a $\mathrm{ZrC}-\mathrm{SiC}$ double-phase coating was fabricated by one-step chemical vapor deposition. A new assistant method for characterizing ablation resistance of ZrC-SiC dispersive biphasic coating on C/C composites was firstly proposed. The change of hardness and elastic modulus of $\mathrm{C} / \mathrm{C}$ substrate before and after ablation were measured, which can reflect the thermal protective ability of the coating accurately. The ablation resistance of the coating was characterized by both this new assistant method and traditional ablation rates. The linear ablation rate of $\mathrm{ZrC}-\mathrm{SiC}$ coating is about $1 / 4$ of that of $\mathrm{ZrC} / \mathrm{SiC}$ coating. The surface of ablated $\mathrm{ZrC}-\mathrm{SiC}$ coating can still keep intact, compared with that of $\mathrm{ZrC}-\mathrm{SiC}$ coating. The hardness and elastic modulus of $\mathrm{C} / \mathrm{C}$ substrate covered by $\mathrm{ZrC}-\mathrm{SiC}$ biphasic coating maintained, which is different than those of $\mathrm{C} / \mathrm{C}$ substrate below $\mathrm{ZrC} / \mathrm{SiC}$ coating. Combining the results obtained from micro-indentation and the ablation rates, it is more convincing that the thermal protective ability of $\mathrm{ZrC}-\mathrm{SiC}$ coating is better than that of $\mathrm{ZrC} / \mathrm{SiC}$ coating. In general, the good ablation resistance can be attributed to the oxygen diffusion blocking and the adhesion effects of $\mathrm{Zr}$-Si-O glass phase. Moreover, the new assistant method for characterizing ablation resistance could be also applied to other coatings for protecting $\mathrm{C} / \mathrm{C}$ composites in the future.

Author Contributions: Conceptualization, T.F. and M.T.; methodology, T.F.; software, M.T.; validation, T.F., M.T. and S.Y.; formal analysis, M.T.; investigation, S.Y.; resources, S.W.; data curation, S.Y.; writing-original draft preparation, S.Y.; writing—-review and editing, T.F.; visualization, M.T.; supervision, T.F.; project administration, T.F.; funding acquisition, T.F.

Funding: This research was funded by the National Natural Science Foundation of China under Grant Nos. 51872237, 51402238; Natural Science Basic Research Plan in Shaanxi Province of China, No. 2017JM5098.

Conflicts of Interest: The authors declare no conflict of interest. The funders had no role in the design of the study; in the collection, analyses, or interpretation of data; in the writing of the manuscript, or in the decision to publish the results.

\section{References}

1. Chang, P.P.; Wang, C.Y.; Kinumoto, T.; Tsumura, T.; Chen, M.M.; Toyoda, M. Frame-filling C/C composite for high-performance EDLCs with high withstanding voltage. Carbon 2018, 131, 184-192. [CrossRef]

2. Mikociak, D.; Rudawski, A.; Blazewicz, S. Mechanical and thermal properties of C/C composites modified with SiC nanofiller. Mater. Sci. Eng. A 2018, 716, 220-227. [CrossRef]

3. Deng, H.; Li, K.; Cui, H.; Li, H.; He, Y.; Zheng, J.; Song, G. Floating catalyst chemical vapor infiltration of nanofilamentous carbon reinforced carbon/carbon composites-Tribological behavior and wear mechanism. Tribol. Int. 2018, 121, 231-240. [CrossRef]

4. Jia, Y.; Li, K.; Zhang, S.; Ren, J. Microstructure and Mechanical Properties of Multilayer-textured 2D Carbon/Carbon Composites. J. Mater. Sci. Technol. 2014, 30, 1202-1207. [CrossRef]

5. Yao, X.; Li, H.; Zhang, Y.; Wang, Y. Oxidation and Mechanical Properties of SiC/SiC-MoSi $2_{2}-Z_{2} B_{2}$ Coating for Carbon/Carbon Composites. J. Mater. Sci. Technol. 2014, 30, 123-127. [CrossRef]

6. Huo, C.; Guo, L.; Cao, A.; Wang, Z.; Wang, C.; Kou, G.; Zhang, Y. The degradation behavior of C/C composites in high-energy atomic oxygen. Vacuum 2017, 146, 120-129. [CrossRef]

7. Wen, G.; Sui, S.; Song, L.; Wang, X.Y.; Xia, L. Formation of ZrC ablation protective coatings on carbon material by tungsten inert gas cladding technique. Corros. Sci. 2010, 52, 3018-3022. [CrossRef]

8. Zhang, Q.; He, J.; Liu, W.; Zhong, M. Microstructure characteristics of ZrC-reinforced composite coating produced by laser cladding. Surf. Coat. Technol. 2003, 162, 140-146. [CrossRef]

9. Jong, H.P.; Choong, H.J.; Do, J.K.; Ji, Y.P. Temperature dependency of the LPCVD growth of ZrC with the $\mathrm{ZrCl}_{4}-\mathrm{CH}_{4}-\mathrm{H}_{2}$ system. Surf. Coat. Technol. 2008, 203, 324-328. 
10. Clavería, I.; Lostalé, A.; Fernández, Á.; Castell, P.; Elduque, D.; Mendoza, G.; Zubizarreta, C. Enhancement of Tribological Behavior of Rolling Bearings by Applying a Multilayer ZrN/ZrCN Coating. Coatings 2019, 9, 434. [CrossRef]

11. Zhang, Y.; Hu, H.; Zhang, P.; Hu, Z.; Li, H.; Zhang, L. SiC/ZrB $2-S i C-Z r C$ multilayer coating for Carbon/Carbon composites against ablation. Surf. Coat. Technol. 2016, 300, 1-9. [CrossRef]

12. Li, B.; Deng, J.; Li, Y. Oxidation behavior and mechanical properties degradation of hot-pressed $\mathrm{Al}_{2} \mathrm{O}_{3} / \mathrm{ZrB}_{2} / \mathrm{ZrO}_{2}$ ceramic composites. Int. J. Refract. Met. Hard Mater. 2009, 27, 747-753. [CrossRef]

13. Li, K.Z.; Wang, S.L.; Li, H.J.; Zhang, Y.L.; Wang, Y.J.; Chen, Z.S. Microstructure and growth mechanism of $\mathrm{ZrO}_{2}$ nanorod network via oxyacetylene torch ablation. Mater. Lett. 2014, 123, 217-220. [CrossRef]

14. Wang, S.L.; Li, K.Z.; Li, H.J.; Zhang, Y.L.; Wang, Y.J. Effects of microstructures on the ablation behaviors of ZrC deposited by CVD. Surf. Coat. Technol. 2014, 240, 450-455. [CrossRef]

15. Zhu, Y.; Cheng, L.; Ma, B.; Gao, S.; Feng, W.; Liu, Y.; Zhang, L. Calculation and synthesis of ZrC by CVD from $\mathrm{ZrCl}_{4}-\mathrm{C}_{3} \mathrm{H}_{6}-\mathrm{H}_{2}$-Ar system with high $\mathrm{H}_{2}$ percentage. Appl. Surf. Sci. 2015, 332, 591-598. [CrossRef]

16. Wang, S.L.; Li, K.Z.; Li, H.J.; Zhang, Y.L.; Zhang, W.Y. Ablation behavior of CVD-ZrC coating under oxyacetylene torch environment with different heat fluxes. Int. J. Refract. Met. Hard Mater. 2015, 48, 108-114. [CrossRef]

17. Xu, Y.; Sun, W.; Xiong, X.; Peng, Z.; Chen, Y.; Hao, Z. Microstructure and properties of ZrC-SiC multi-phase coatings prepared by thermal evaporation deposition and an in-situ reaction method. Surf. Coat. Technol. 2018, 349, 797-806. [CrossRef]

18. Jia, Y.; Li, H.; Fu, Q.; Zhao, Z.; Sun, J. Ablation resistance of supersonic atmosphere plasma spraying ZrC coating doped with $\mathrm{ZrO}_{2}$ for SiC-coated carbon/carbon composites. Corros. Sci. 2017, 123, 40-54. [CrossRef]

19. Xu, J.; Yang, T.; Yang, Y.; Qian, Y.; Li, M.; Yin, X. Ultra-high temperature oxidation behavior of micro-laminated ZrC/MoSi 2 coating on C/C composite. Corros. Sci. 2018, 132, 161-169. [CrossRef]

20. Zhou, Z.; Sun, Z.; Ge, Y.; Peng, K.; Ran, L.; Yi, M. Microstructure and ablation performance of SiC-ZrC coated $\mathrm{C} / \mathrm{C}$ composites prepared by reactive melt infiltration. Ceram. Int. 2018, 44, 8314-8321. [CrossRef]

21. Zhuang, L.; Fu, Q.G.; Zhang, J.P.; Guo, Y.A.; Li, H.J.; Shan, Y.C. Effect of pre-oxidation treatment on the bonding strength and thermal shock resistance of $\mathrm{SiC}$ coating for $\mathrm{C} / \mathrm{C}-\mathrm{ZrC}-\mathrm{SiC}$ composites. Ceram. Int. 2015, 41, 6956-6964. [CrossRef]

22. Jia, Y.; Li, H.; Li, L.; Fu, Q.; Li, K. Effect of Monolithic LaB6 on the Ablation Resistance of ZrC/SiC Coating Prepared by Supersonic Plasma Spraying for C/C Composites. J. Mater. Sci. Technol. 2016, 32, 996-1002. [CrossRef]

23. Shi, X.H.; Huo, J.H.; Zhu, J.L.; Liu, L.; Li, H.J.; Hu, X.J.; Li, M.Y.; Guo, L.J.; Fu, Q.G. Ablation resistance of $\mathrm{SiC}-\mathrm{ZrC}$ coating prepared by a simple two-step method on carbon fiber reinforced composites. Corros. Sci. 2014, 88, 49-55. [CrossRef]

24. Xu, Y.; Sun, W.; Xiong, X.; Zhan, Z.; Tian, T.; Chen, Y.; Peng, Z. Microstructure and ablation resistance of $\mathrm{ZrC}_{\mathrm{x}} \mathrm{N}_{\mathrm{y}}$-modified $\mathrm{ZrC}$-SiC composite coating for carbon/carbon composites. J. Eur. Ceram. Soc. 2018, 38, 4363-4372. [CrossRef]

25. Bu, A.; Zhang, Y.; Zhang, Y.; Chen, W.; Cheng, H.; Wang, L.; Wang, Y. A Novel Electrolytic Plasma Spraying Preparation $\mathrm{SiO}_{2} / \mathrm{SiC}$ Coating on Carbon Fiber Fabric. Coatings 2018, 8, 344. [CrossRef]

26. Mallik, M.; Ray, K.; Mitra, R. Effect of $\mathrm{Si}_{3} \mathrm{~N}_{4}$ Addition on Oxidation Resistance of $\mathrm{ZrB}_{2}$-SiC Composites. Coatings 2017, 7, 92. [CrossRef]

27. Zhang, Z.; Nan, C.; Xu, J.; Gao, Z.; Li, M.; Wang, J. Oxidation Behaviors of C-ZrB 2 -SiC Composite at 2100 degrees $\mathrm{C}$ in Air and $\mathrm{O}_{2}$. J. Mater. Sci. Technol. 2014, 30, 266-268.

28. He, Q.; Li, H.; Wang, C.; Li, T.; Lu, J. Microstructure and ablation property of gradient ZrC SiC modified C/C composites prepared by chemical liquid vapor deposition. Ceram. Int. 2019, 45, 20414-20426. [CrossRef]

29. Liu, T.; Niu, Y.; Pan, X.; Shi, M.; Zheng, X.; Yu, J.; Ding, C. Laser ablation behaviors of vacuum plasma sprayed ZrC-based coatings. J. Am. Ceram. Soc. 2019, 102, 4247-4258. [CrossRef]

30. Liu, Q.; Liu, J.; Luan, X. Preparation of ZrC-SiC composite coatings by chemical vapor deposition and study of co-deposition mechanism. J. Mater. Sci. Technol. 2019. [CrossRef]

(C) 2019 by the authors. Licensee MDPI, Basel, Switzerland. This article is an open access article distributed under the terms and conditions of the Creative Commons Attribution (CC BY) license (http://creativecommons.org/licenses/by/4.0/). 